\title{
NUMERICAL RESEARCH ON DYNAMIC LOADS OF WHEELED ARMOURED PERSONNEL CARRIER DURING OVERCOMING TERRAIN OBSTACLES
}

\author{
Wacław Borkowski, Bogusław Michałowski, Piotr Rybak, Andrzej Wiśniewski \\ Military University of Technology \\ Faculty of Mechanical Engineering \\ Kaliskiego Street 2, 00-908 Warsaw, Poland \\ tel.: +4822 6897752, fax.: +48226837370 \\ e-mail:wborkowski@wat.edu.pl,bmichalowski@wat.edu.pl \\ prybak@wat.edu.pl,wisniewskia@wat.edu.pl
}

\begin{abstract}
Paper presents the results of numerical research on the influence of the movement conditions (velocity and various types and parameters of obstacles) on the level of dynamic loads of the body shell and the vehicle crew of the basic version of Wheeled Armoured Personnel Carrier (Wheeled APC) ROSOMAK. The research work was aimed at analysis of the dynamic loads resulting from the overcoming various terrain obstacles. Kinematic constraints acting on suspension used during tests were random and deterministic, e.g. sine, cosine, triangle as well as mixed, imitating fallen tree trunk on smooth surface. Simulations were carried out with the genuine proprietary software for numerical analysis of dynamics of multi-axis vehicles equipped with independent suspension. The paper consists description of the mathematical model of multi-axis vehicle, deterministic and random generated inputs and range of performed tests. Time courses of displacement, velocity, vertical and angular (longitudinal and transverse) accelerations were determined for chosen parts of vehicle. Paper also contains time courses of deflection for every suspension wheel and dynamical reactions of the ground as well as selected time charts and cumulative statistics. Finally paper presents conclusions formulated about dynamic loads of APC ROSOMAK depending on parameters and types of obstacles and vehicle velocity.
\end{abstract}

Keywords: numerical research, dynamical loads, wheeled armoured personnel carrier, simulation

\section{Introduction}

Special vehicles, especially military combat vehicles, including wheeled armoured personnel carriers require high ability to overcome natural and artificial obstacles, or engineered roadblocks that reduce trafficability. These requirements apply to day and night operation, and limited visibility conditions. Due to assure safety of the crew, before the test drive it is advisable to perform numerical research, that will determine level of dynamic loads and vehicle stability during overcoming various obstacles. The simulation were carried out using genuine numerical software which is a part of didactical packet "DYD ZPG", developed in Institute Of Motor Vehicles and Transportation FME MUT. The software allows to solve complex problems in the field of vehicle dynamics and is capable to analyse dynamical loads while overcoming obstacles that may be similar to: fallen tree trunk on smooth surface, terrain roads (also wilderness), single cosine or triangle shaped obstacles, counterscarp or the antitank ditch. The kinds of kinematic constraints have been defined on observations of most often encountered shapes of roughness as well as information about applied solutions from literature [3]. There is also possibility to mix deterministic and random generated inputs to check e.g. fallen tree on soil-surfaced road. Onesided constraints of shore elements corresponding to driving wheels allow to gain the effect of detaching the ground and test the stability of vehicle. Results of simulations have been favourably verified during field experiment. 


\section{Object of research}

Object of research was the model formulated on basis of Wheeled Armoured Personnel Carrier (Wheeled APC) ROSOMAK in basic variant. This variant has no turret nor other weapon system. It is not equipped with seats for the infantry troops as well. It comprises the basis to build combat variants, e.g. battlefield command vehicle, medical evacuation vehicle, mobile mortar or mobile air-defense vehicle. Appearance of APC has been presented in Fig. 1, and the basic technical parameters were shown in Tab. 1.

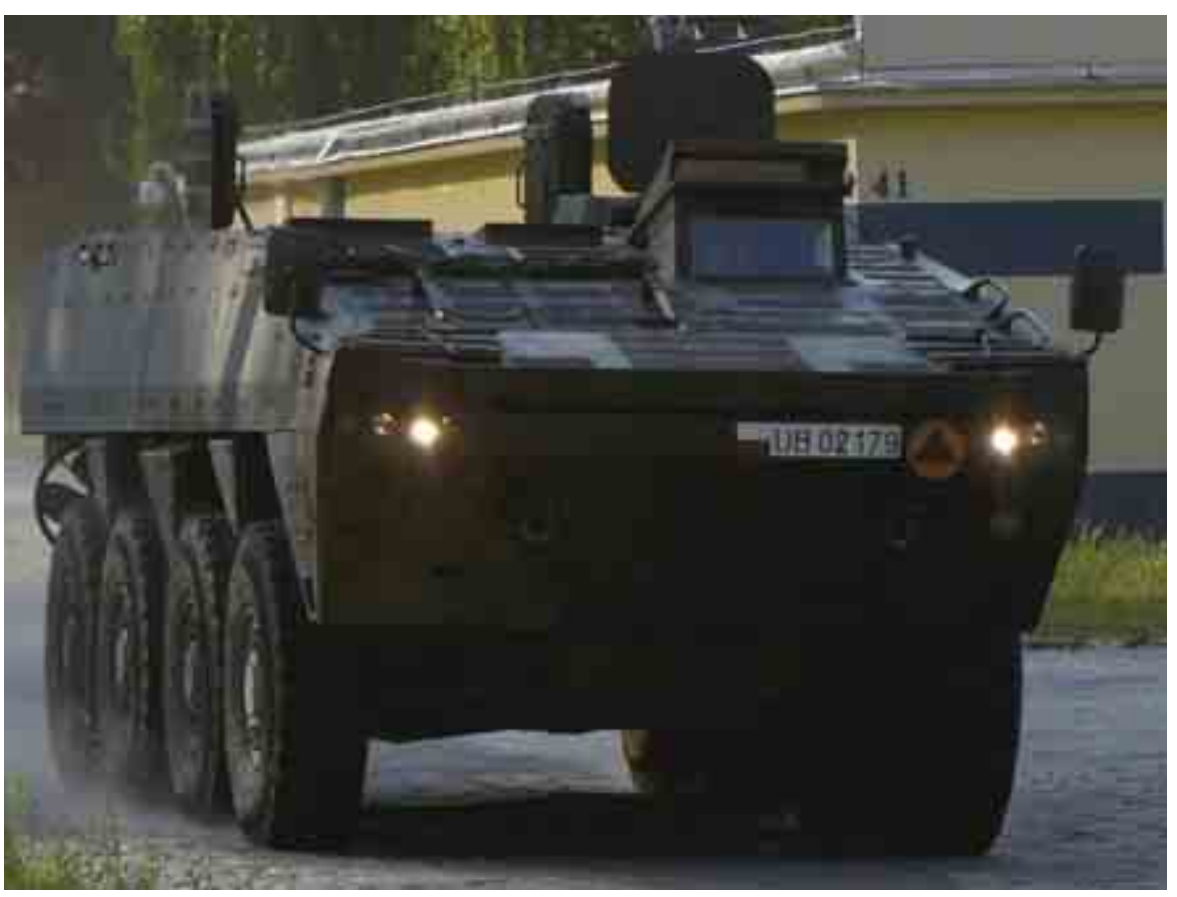

Fig. 1. Object of research

Tab. 1. Basic parameters of APC Rosomak

\begin{tabular}{|c|l|c|c|}
\hline Number & \multicolumn{1}{|c|}{ Parameter } & Value & Unit \\
\hline 1. & Overall length & $L_{k}$ & $\mathrm{~mm}$ \\
\hline 2. & Overall width & $B_{k}$ & $\mathrm{~mm}$ \\
\hline 3. & Wheelbase & $(a)$ & $\mathrm{mm}$ \\
\hline 4. & Ground clearance & $h_{p}$ & $\mathrm{~mm}$ \\
\hline 5. & Height without turret & $H_{\max }$ & $\mathrm{mm}$ \\
\hline 6. & Immersion depth & 2400 & $\mathrm{~mm}$ \\
\hline 7. & Total mass & $m_{b}$ & $\mathrm{~kg}$ \\
\hline 8. & Maximum speed & 100 & $\mathrm{~km} / \mathrm{h}$ \\
\hline 9. & Maximum slope & 60 & $\%$ \\
\hline 10. & Maximum transverse & 35 & $\%$ \\
\hline 11. & Fording depth & 1.5 & $\mathrm{~m}$ \\
\hline 12. & Height of the obstacle & 0.5 & $\mathrm{~m}$ \\
\hline 13. & Width of ditch & 2.1 & $\mathrm{~m}$ \\
\hline
\end{tabular}




\section{Simulation studies}

\subsection{Physical and mathematical models of object}

The physical model of the vehicle, based on the work described in [2] had fourteen degrees of freedom. Essential components of the model were: vehicle hull, seats of the crew, elastic and damping elements of suspension, and driving wheels. Vehicle hull was a rigid body (Fig. 2), with three degrees of freedom (vertical translation, longitudinal and transversal rotation). Seat of driver was represented by centred mass of three degrees of freedom, embedded on four elasto-damping elements, which lower ends were connected with vehicle frame construction. Model also took into consideration moments of inertia of the hull and seat. There were also tested dynamic loads acting on the other members of the crew by placing the seat in proper place. Vehicle body was suspended on elasto-damping elements. Wheel hubs were also centred masses of one degree of freedom (vertical translation), supported with elasto-damping elements that represent stiffness and damping of tires. Applied in program segment approximation of nonlinear characteristics of spring and damping elements allows to model various types of suspension e.g. helical springs, torsion bars and hydro-pneumatic strut. At the stage of verifying the model faultless they were linearized as a rule and then used nonlinear in accurate tests.

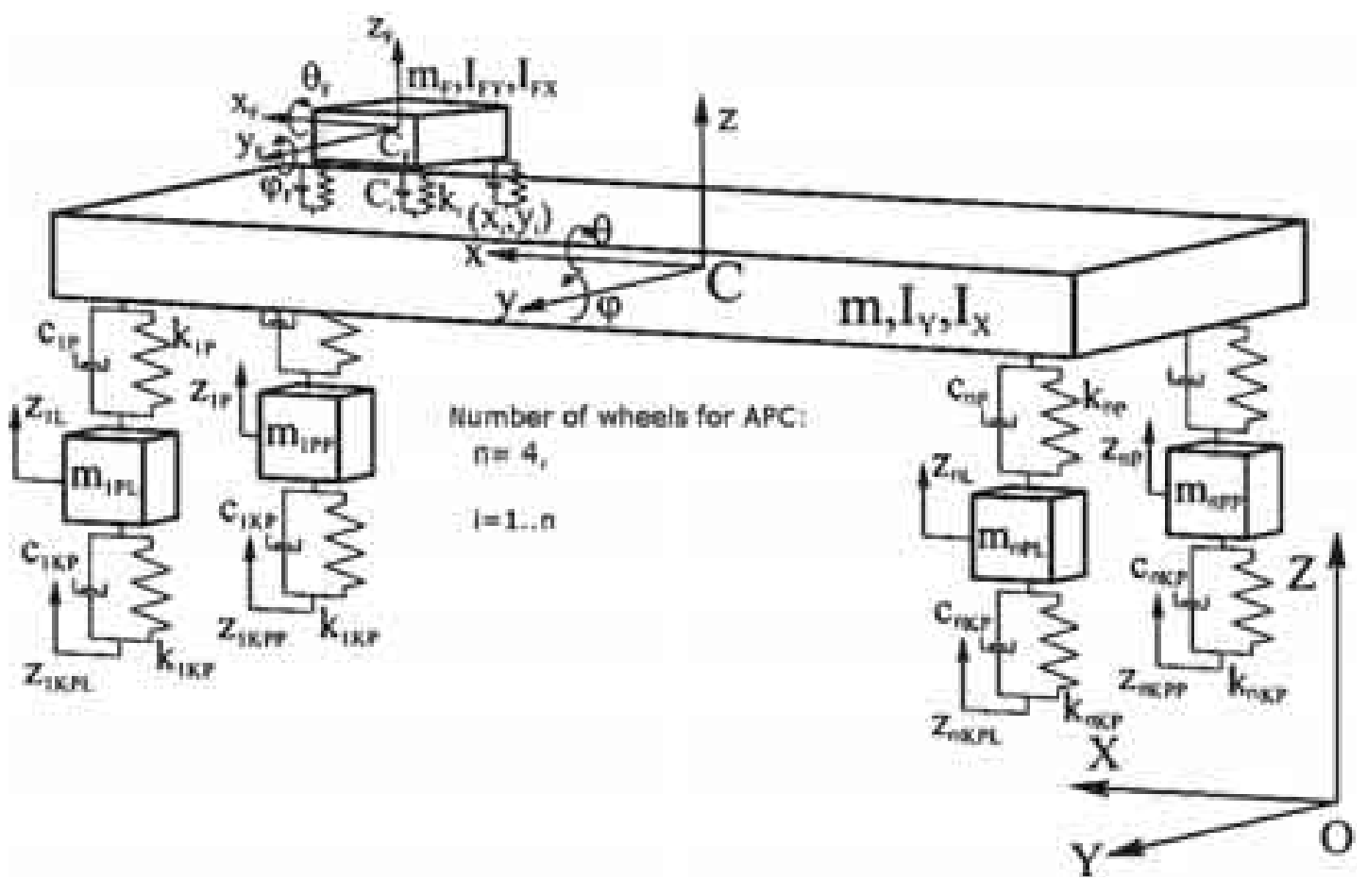

Fig. 2. APC Rosomak discrete model

Matrix equation of the nonlinear motion model eq. (1) was formulated using principles of d'Alambert:

$$
M \ddot{q}=F
$$

where:

$\boldsymbol{M}$ - the matrix of model inertia,

$\ddot{q}$ - vector of generalized accelerations,

$\boldsymbol{F}$ - vector of generalized forces.

Roughness affects the sprung mass at the points of attachment elements of suspension to vehicle body by the forces of elasticity and damping. Interaction of wheels with the ground is 
estimated by the value of unilateral vertical reaction of ground. This is important to evaluate the stability of the vehicle during overcoming obstacles including the estimation of critical speed depending on the parameters of the ground.

\subsection{Models of constraints}

In the tests were used various models obstacles in the form of:

a) ramp (counterscarp) described by dependency:

$$
z(t)=h\left(1-e^{-\gamma v t}\right),
$$

b) single obstacle (tree trunk, ditch) with cosine profile described by dependency:

$$
z(t)=\frac{h}{2}\left(1-\cos \left(\frac{2 \pi v t}{L}\right)\right)
$$

c) single obstacle (ditch) with triangular profile described by dependency:

$$
\mathrm{z}(\mathrm{t})= \begin{cases}\frac{2 \cdot \mathrm{h}}{\mathrm{L}}(\mathrm{v} \cdot \mathrm{t}) & - \text { for } 0 \leq \mathrm{t} \leq \frac{L}{2 \cdot v}, \\ \frac{2 \cdot \mathrm{h}}{\mathrm{L}}(\mathrm{L}-\mathrm{v} \cdot \mathrm{t}) & - \text { for } \frac{L}{2 \cdot v}<\mathrm{t} \leq \frac{L}{v}, \\ 0 & - \text { for } \mathrm{t}>\frac{L}{v},\end{cases}
$$

d) random kinematic extortion described by dependency:

$$
\mathrm{z}(\mathrm{t})=\sum_{\mathrm{k}=1}^{n} \sqrt{\frac{G_{w}\left(\Omega_{o}\right) \cdot \Delta \omega \cdot v^{w-1}}{(\mathrm{k} \cdot \Delta \omega)^{w}}} \cdot \cos \left(\mathrm{k} \cdot \Delta \omega \cdot \mathrm{t}-\varphi_{\mathrm{k}}\right),
$$

where:

$h \quad-$ height of obstacle [m],

$v \quad-$ vehicle speed $[\mathrm{m} / \mathrm{s}]$,

$L \quad-$ length of extortion waveform [m],

$\gamma \quad-$ smoothing factor of stroke unit threshold (as a result of the interaction of tyre elasticity),

$\Omega_{\mathrm{o}} \quad-$ frequency of the reference (most commonly $\Omega_{\mathrm{o}}=1 / \mathrm{m}$ ),

$G_{w}\left(\Omega_{\mathrm{o}}\right)$ - spectral density ratio of the road roughness $\left[\mathrm{m}^{3}\right]$,

$w \quad-$ waviness index,

$\Delta \omega \quad-$ basis frequency of the harmonic extortion.

The program allows to combine stochastic and deterministic constraints. With appropriate preparation of input data (e.g., the negative value of height) can also simulate transverse ditch.

The study concludes various vehicle speed drive through various obstacles like fallen tree trunk, antitank ditch, or counterscarp on smooth surface and unsurfaced road (wilderness). Some of the obtained results is shown below.

\subsection{Numerical tests results}

The first calculation was for overcoming of fallen tree trunk. There was two variants of this obstacle. The first has the parameters $\mathrm{L}=0.3 \mathrm{~m}, \mathrm{~h}=0.15 \mathrm{~m}(\mathrm{D} 1)$, while the second $\mathrm{L}=0.3 \mathrm{~m}$, $\mathrm{h}=0.3 \mathrm{~m}$ (D2). Time charts of acceleration for centre of mass and driver seat for chosen variant is shown in Fig. 3. Extreme values of vertical accelerations for centre of mass and the driver seat for different velocities of APC are shown in Tab. 2. 


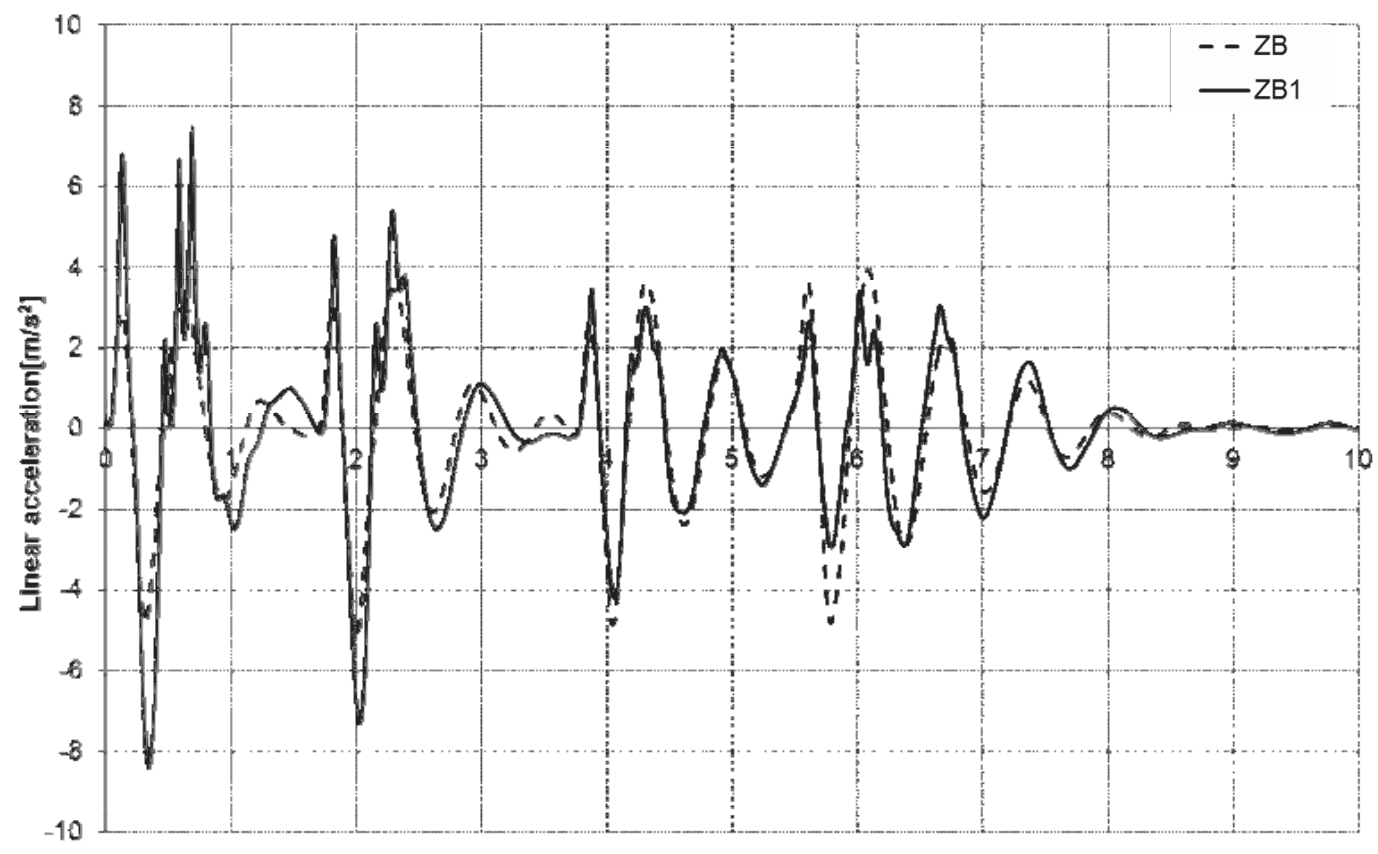

Time [s]

Fig. 3. Time chart of acceleration for centre of mass and the driver seat (D1, $3 \mathrm{~km} / \mathrm{h})$

Tab. 2. Statistical summary of acceleration values for different velocities and variants

\begin{tabular}{|c|c|c|c|c|}
\hline \multirow{2}{*}{ Extortion/velocity } & \multicolumn{4}{|c|}{ Acceleration $\left[\mathrm{m} / \mathbf{s}^{2}\right]$} \\
\cline { 2 - 5 } & \multicolumn{2}{|c|}{ Centre of mass (ZB) } & \multicolumn{2}{c|}{ Driver seat (ZB1) } \\
\hline $\boldsymbol{D} 1$ & Max & Min & Max & Min \\
\hline $1 \mathrm{~km} / \mathrm{h}$ & 1.58 & -1.41 & 3.02 & -2.56 \\
\hline $3 \mathrm{~km} / \mathrm{h}$ & 3.95 & -5.14 & 7.48 & -8.40 \\
\hline $5 \mathrm{~km} / \mathrm{h}$ & 5.72 & -5.59 & 15.00 & -9.06 \\
\hline $\boldsymbol{D 2}$ & Max & Min & Max & Min \\
\hline $3 \mathrm{~km} / \mathrm{h}$ & 7.13 & -8.49 & 25.50 & -12.40 \\
\hline
\end{tabular}

Tab. 3. Statistical summary of acceleration values for passage across the ditch, where "ZB" is centre of mass and " $Z B 1$ " is driver seat

\begin{tabular}{|c|c|c|c|c|}
\hline \multirow{2}{*}{ Extortion } & \multicolumn{4}{|c|}{ Acceleration $\left[\mathrm{m} / \mathbf{s}^{2}\right]$} \\
\cline { 2 - 5 } & \multicolumn{2}{|c|}{ Max } & \multicolumn{2}{c|}{ Min } \\
\cline { 2 - 5 } & $\mathbf{Z B}$ & $\mathbf{Z B 1}$ & -1.66 & -2.28 \\
\hline $\mathrm{h}=-1 \mathrm{~m}, \mathrm{~L}=4 \mathrm{~m}, \mathrm{v}=2 \mathrm{~km} / \mathrm{h}$ & 2.87 & 3.9 & -3.78 & -3.86 \\
\hline $\mathrm{h}=-2 \mathrm{~m}, \mathrm{~L}=4 \mathrm{~m}, \mathrm{v}=2 \mathrm{~km} / \mathrm{h}$ & 3.98 & 12.3 & -4.57 & -6.03 \\
\hline $\mathrm{h}=-1 \mathrm{~m}, \mathrm{~L}=4 \mathrm{~m}, \mathrm{v}=5 \mathrm{~km} / \mathrm{h}$ & 6.98 & 19.7 & & \\
\hline
\end{tabular}


Analysis of the obtained results allows to assume, that in tested conditions APC Rosomak is able to overcome obstacles for a given velocity. Note that when increasing velocity of carrier results significant increasing of extreme vertical accelerations. On the other hand when the height of obstacle doubles and a velocity is equal $3 \mathrm{~km} / \mathrm{h}$ then extreme values of acceleration are much greater (over 3 times for driver seat) than lower obstacle at highest tested velocity.

Displacements of the wheels, dynamical reactions of ground and accelerations for driver seat and centre of mass while overcoming the ditch are presented in Fig. 4-6. The results for the other speed and input parameters are summarized in Tab. 3.

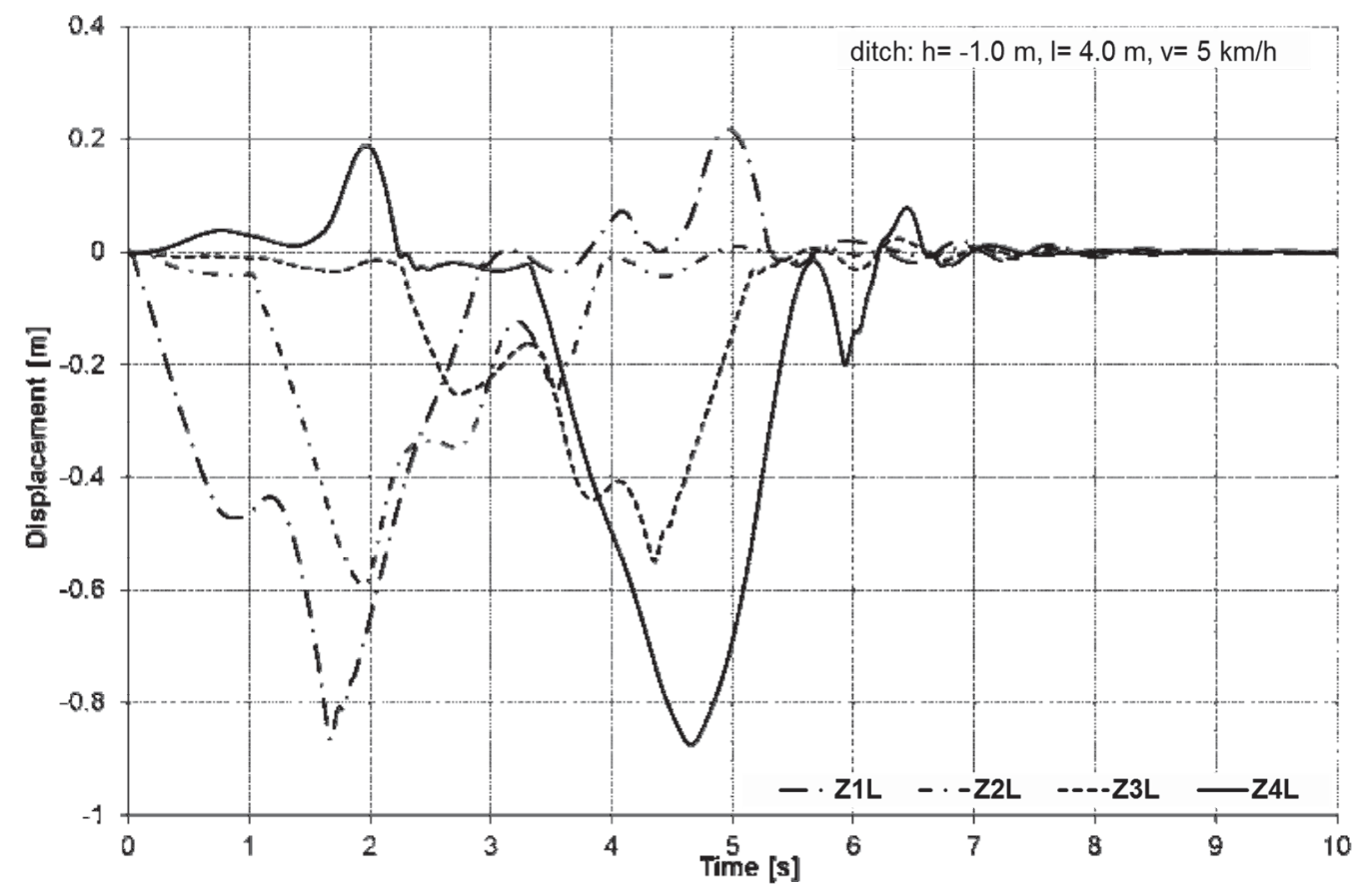

Fig. 4. Time chart of wheels vertical displacement

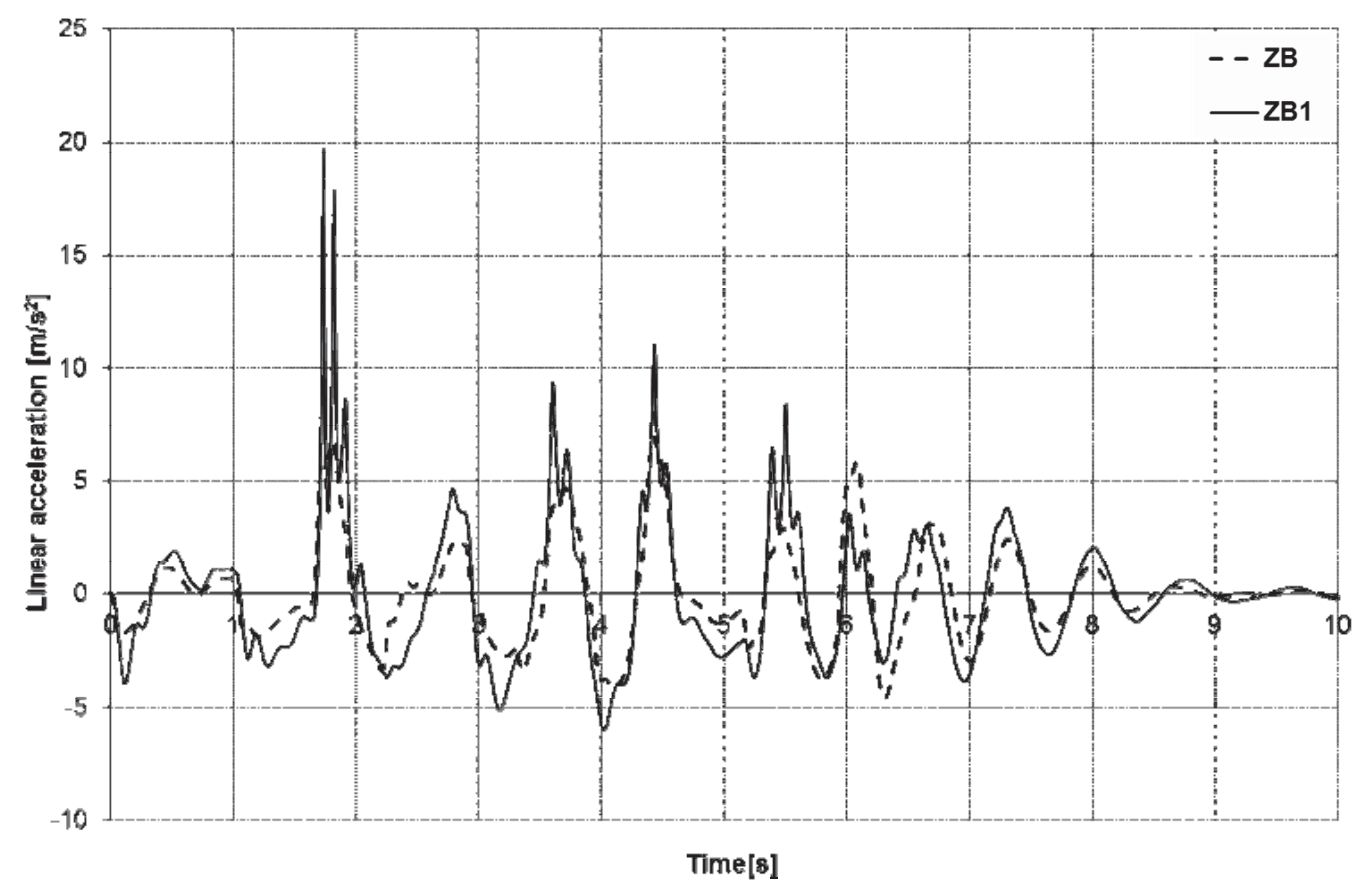

Fig. 5. Time chart of vertical acceleration of centre of mass (ZB) and driver seat (ZB1) 


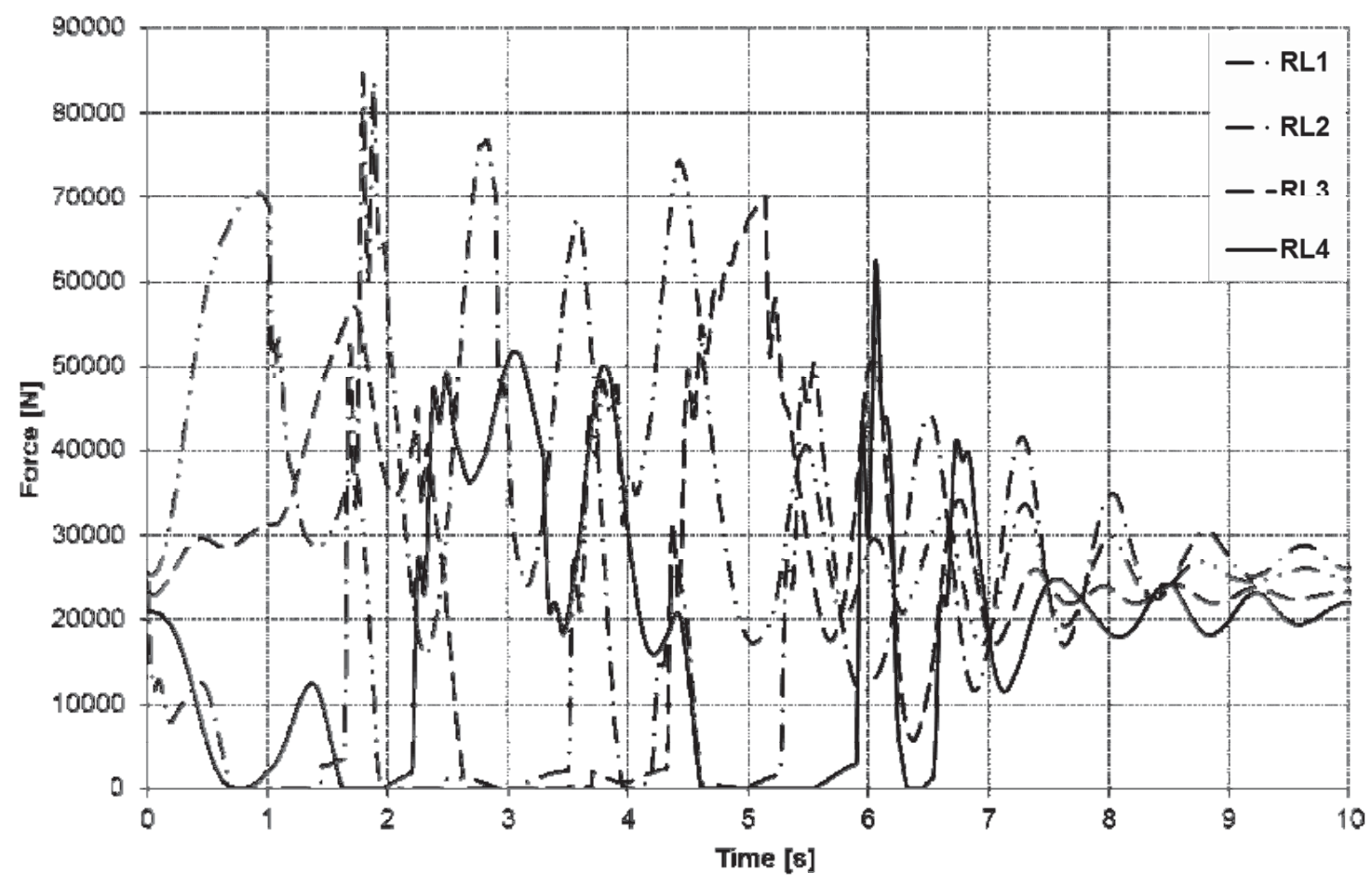

Fig. 6. Time chart of dynamic ground reactions from (L1-double dot, ..., L4 number of wheel)

For analysed runs can be seen clearly that increasing vehicle velocity as well as depth of the ditch causes increasing of dynamical loads. Time charts of vertical displacements, dynamical reactions from ground and accelerations for centre of mass and driver seat during overcoming counterscarp are presented in Fig. 7-9. By comparing them the process of overcoming obstacles can be traced and analysed.

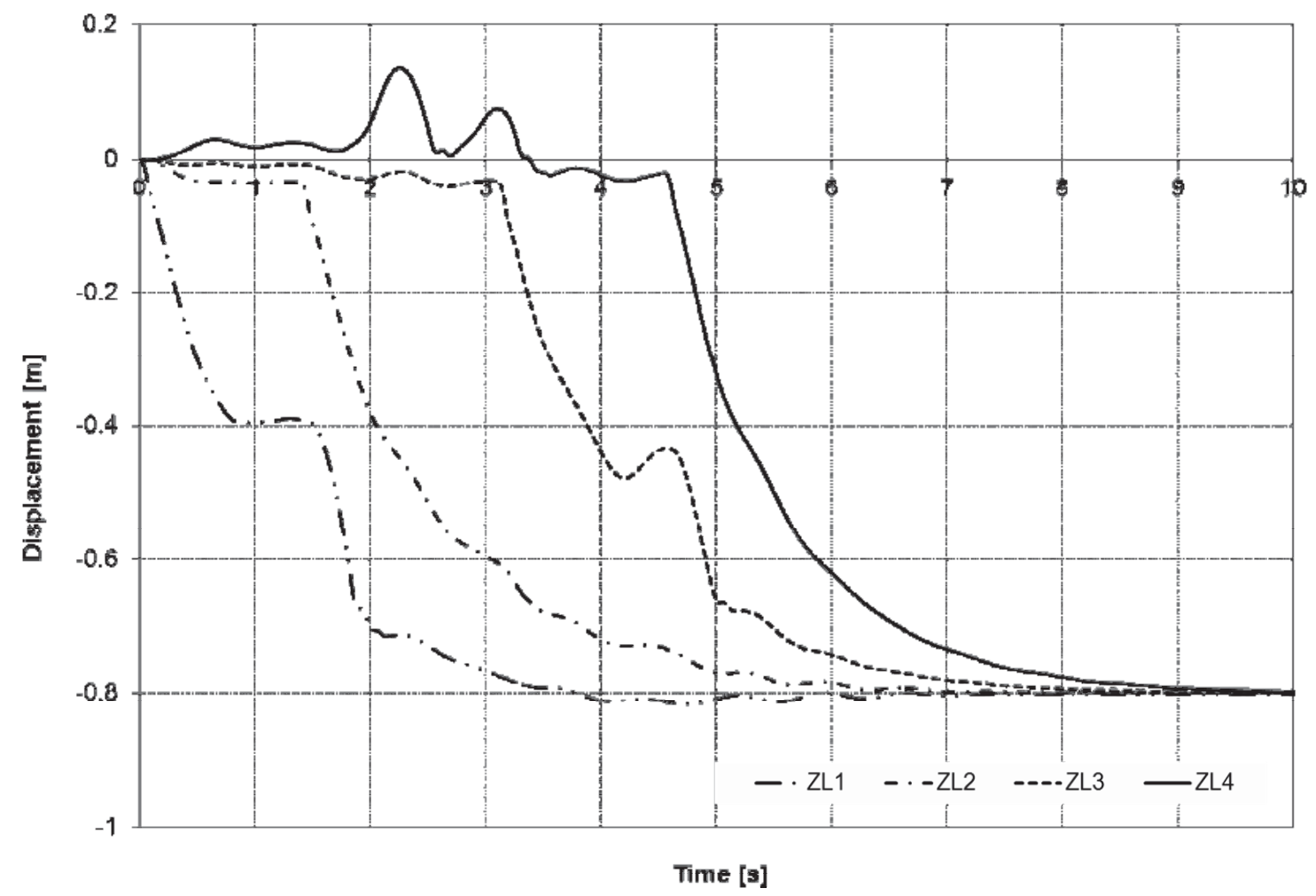

Fig. 7. Time chart of vertical wheel displacement, counterscarp, $h=0.8 \mathrm{~m}, v=3.6 \mathrm{~km} / \mathrm{h}$ 


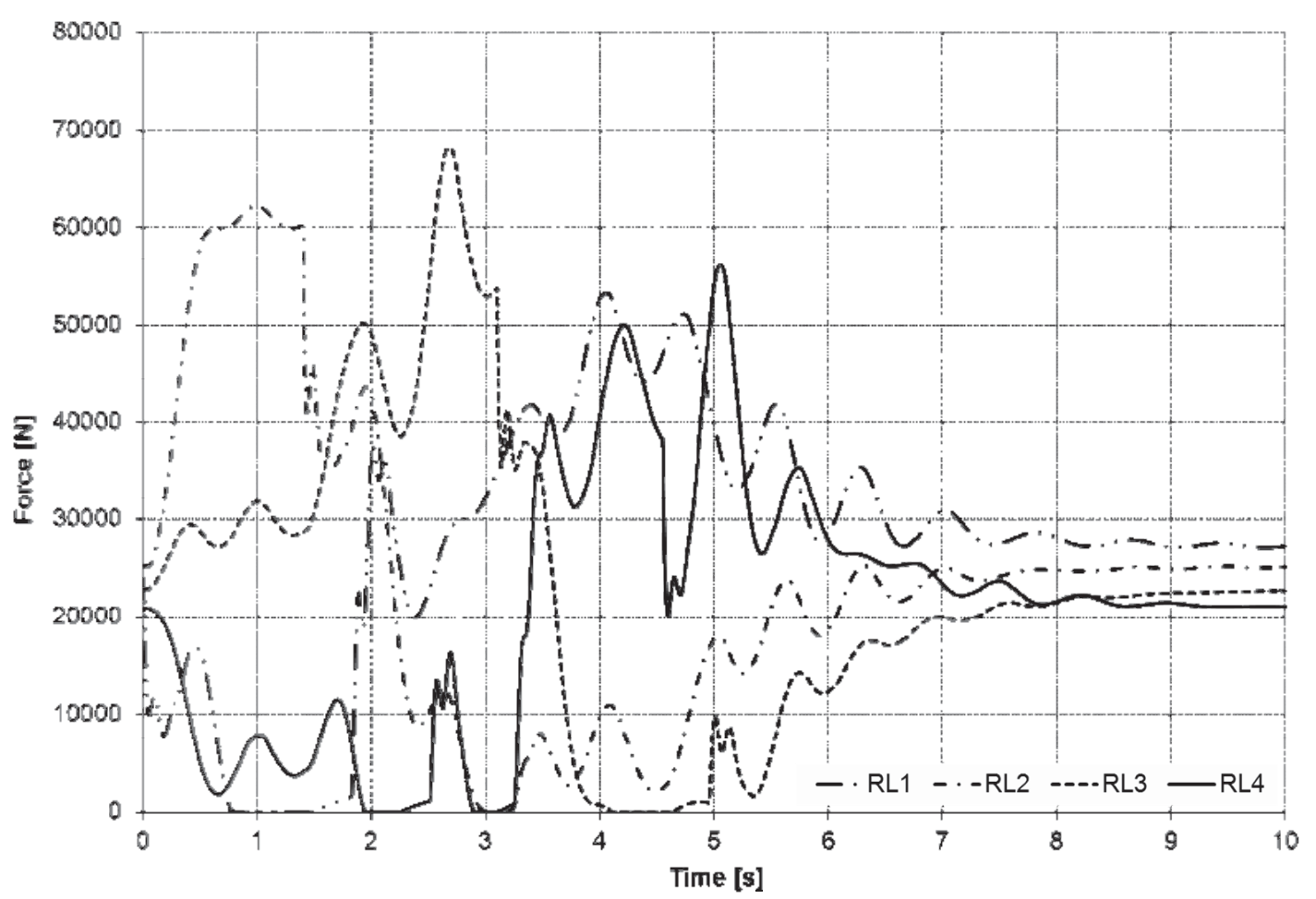

Fig. 8. Time chart of dynamical ground reactions, counterscarp (L1-double dot, ..., L4 number of wheel)

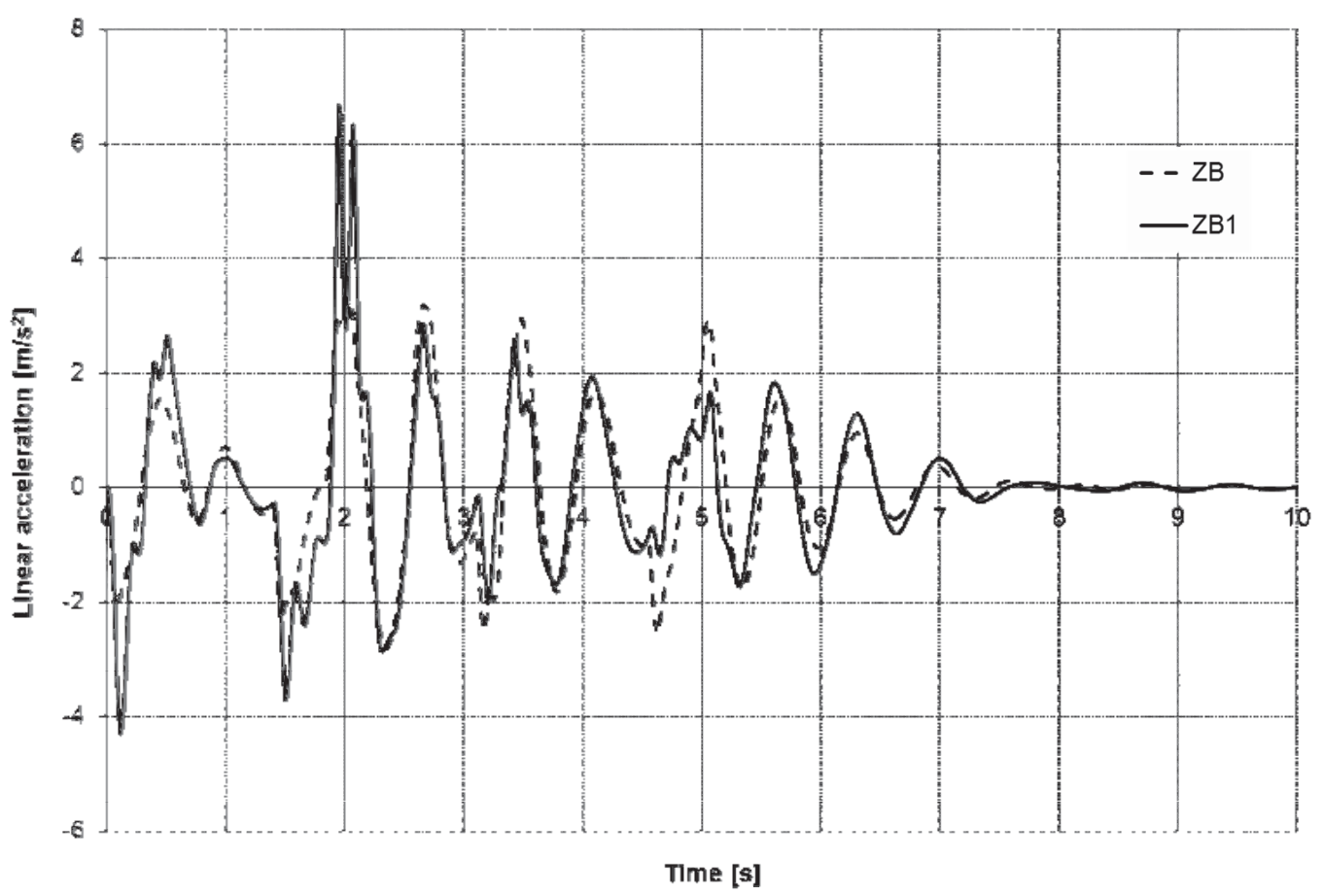

Fig. 9. Time chart of vertical accelerations for centre of mass and driver seat

Observed in 2 second of the movement increase of driver seat acceleration is caused by longitudinal tilt of the hull supported only on second (single dot line) and third (dashed line) suspension and contact of the first driving wheel (double dot) with the ground.

During the test with constant velocity of vehicle maximum accelerations acting on the driver are close to $6.7 \mathrm{~m} / \mathrm{s}^{2}$, and $-4.3 \mathrm{~m} / \mathrm{s}^{2}$. Smaller values of accelerations occur for the centre of mass and are $3.3 \mathrm{~m} / \mathrm{s}^{2}$, and $-2.8 \mathrm{~m} / \mathrm{s}^{2}$ respectively. The reason of that results from combining vertical and angular accelerations from centre of mass that affect on the driver. 
Sample time chart of vertical accelerations for centre of mass and the driver seat with velocity about $4 \mathrm{~km} / \mathrm{h}$ through unsurfaced, very poor quality road (wilderness) was shown in the Fig. 10. The height of roughness sometimes exceeds $0.5 \mathrm{~m}$. Extreme values of accelerations for other velocities are summarized in Tab. 4.

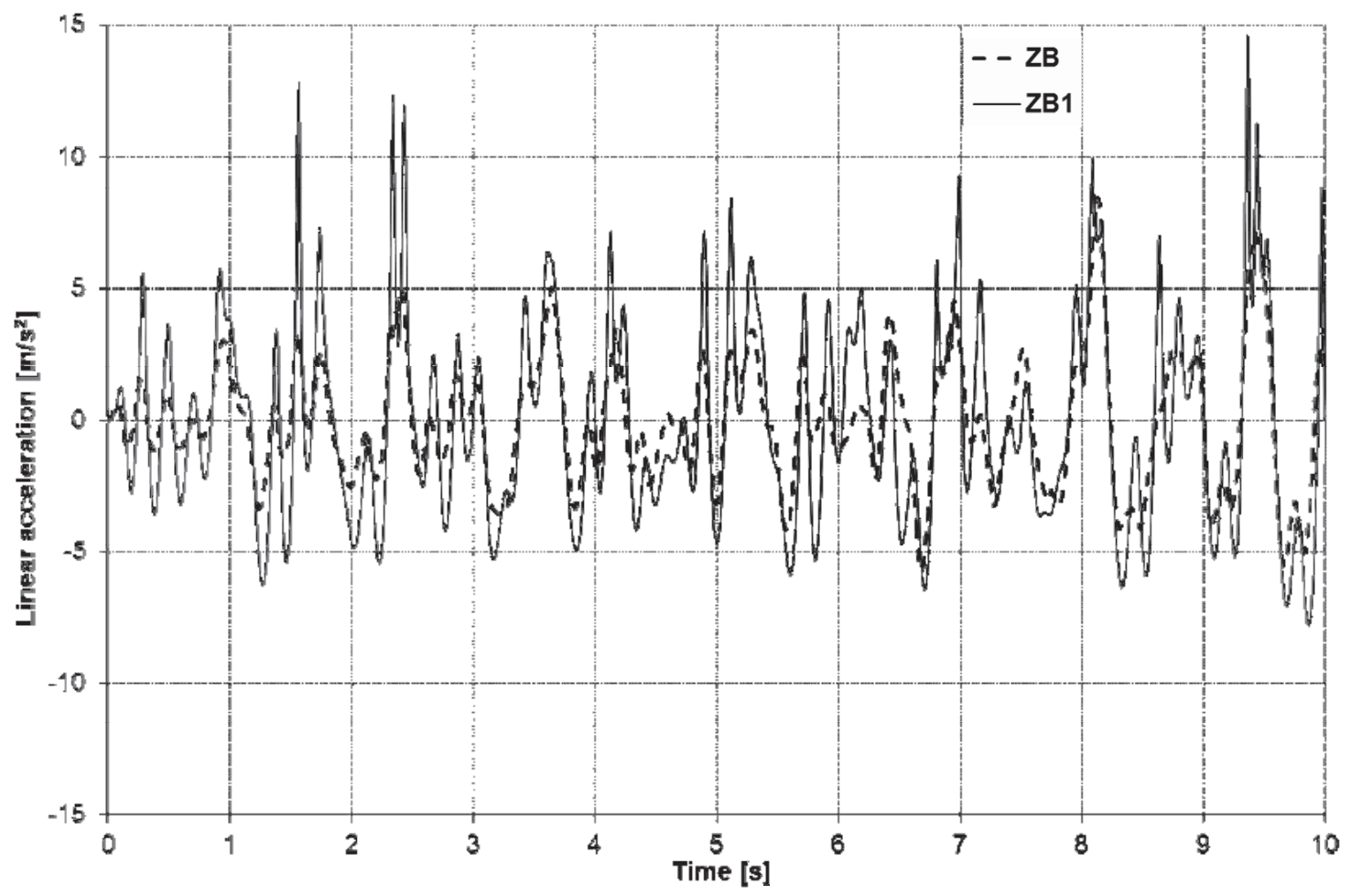

Fig. 10. Time chart of vertical accelerations for centre of mass and driver seat, wilderness, $v=4 \mathrm{~km} / \mathrm{h}$

Tab. 4. Statistical summary of acceleration values for passage across wilderness

\begin{tabular}{|c|c|c|c|c|c|c|}
\hline \multirow{2}{*}{$\begin{array}{c}\text { Velocity } \\
{[\mathbf{k m} / \mathbf{h}]}\end{array}$} & \multicolumn{6}{|c|}{ Acceleration $\left[\mathrm{m} / \mathbf{s}^{2}\right]$} \\
\cline { 2 - 7 } & $\mathbf{Z B}$ & $\mathbf{Z B 1}$ & $\mathbf{Z B}$ & $\mathbf{Z B 1}$ & $\mathbf{Z}$ & $\mathbf{Z}$ \\
\cline { 2 - 7 } & 2.17 & 3.89 & -1.68 & -2.25 & 0.58 & 0.8 \\
\hline 1 & 7.71 & 12.5 & -7.75 & -9.35 & 1.96 & 2.50 \\
\hline 2 & 11.3 & 20.9 & -10.0 & -11.1 & 3.47 & 4.43 \\
\hline 4
\end{tabular}

Numerical research results lead to the conclusion that long-term off-road driving (similar to typical tank roads) are onerous conditions for the APC driver. As in overcoming deterministic types of obstacles there is visible phenomenon of increasing accelerations of the driver seat relative to the mass centre accelerations. Peak value of the seat vertical accelerations reaches $20.9 \mathrm{~m} / \mathrm{s}^{2}$ while the mass centre reaches only $11.3 \mathrm{~m} / \mathrm{s}^{2}$ for the velocity $4 \mathrm{~km} / \mathrm{h}$.

However for single obstacle like fallen tree or ditch values of vertical accelerations shouldn't negatively affect on psychophysical condition of the driver, but in case of driving the long-term off-road driving on unsurfaced roads (very bad quality) their influence can be significant. 


\section{Summary}

The paper demonstrates a wide spectrum of usability of the software in analysis of dynamical loads of exemplary vehicle during overcoming obstacles. Program allows to determine level of dynamical loads affecting on vehicle and its crew and estimate critical velocities for overcoming obstacles. For more comprehensive description for phenomena of approaching obstacle with height comparable with wheel diameter and high approach angle should be analysed horizontal reactions due to influence of inertia on longitudinal angular accelerations of vehicle body.

\section{Acknowledgement}

The scientific work financed by the funds assigned for the science in years 2010-2013 as a research project.

\section{References}

[1] Mitschke, M., Dynamika samochodu, WKiŁ, Warszawa 1977.

[2] Borkowski, W., Rybak, P., Hryciów, Z., Michałowski, B., Wpływ stanu technicznego zawieszenia na obciążenia dynamiczne pojazdu specjalnego, Teka komisji motoryzacji, Z. Nr 33/34, Kraków 2008.

[3] Generalna dyrekcja dróg publicznych, Rowy, Ogólne specyfikacje techniczne, Warszawa 1998.

[4] Borkowski, W., Michałowski, B., Rybak, P., Wiśniewski, A., Analiza obciążén dynamicznych transportera opancerzonego przy pokonywaniu przeszkód terenowych, XII Konferencja N-T Techniki Komputerowe w Inżynierii, Słok k/Bełchatowa 2011.

[5] Rybak, P., Borkowski, W., Hryciów, Z., Wysocki, J., Michałowski, B., Badanie obciążeń dynamicznych pojazdów mechanicznych $w$ aspekcie bezpieczeństwa oraz komfortu jazdy, Systems Journal of Transdisciplinary Systems Science, Vol. 16, No. 1, Wrocław 2012. 